\title{
SPOŁECZNA ODPOWIEDZIALNOŚĆ BIZNESU CZY CELOWE DZIAŁANIA MARKETINGOWE? - ANALIZA PRZYPADKU PRZEDSIĘBIORSTWA NEXT PLC
}

Zarys treści: W artykule zaprezentowano analizę przypadku przedsiębiorstwa Next plc pod kątem stosowania praktyk z zakresu społecznej odpowiedzialności biznesu. Skoncentrowano się na trzech zasobach, jakimi są klienci, pracownicy oraz produkty. Koncepcja CSR stanowi w dzisiejszych czasach ważny element prosperowania przedsiębiorstw w otoczeniu, a mnogość zachowań analizowanego przypadku w tym aspekcie jest tego potwierdzeniem.

Słowa kluczowe: społeczna odpowiedzialność biznesu; raporty CSR; CSR; etyka biznesu.

Klasyfikacja JEL: M30.

\section{WSTĘP}

W dzisiejszych czasach większość dużych przedsiębiorstw głosi, że stosuje politykę społecznie odpowiedzialnego biznesu, co objawia się między innymi budowaniem pozytywnych relacji ze wszystkimi członkami otoczenia firmy, dbaniem o środowisko naturalne, a także kreowaniem pozytywnego wizerunku marki. Jest to sposób na sprostanie coraz wyższym oczekiwaniom

* Adres do korespondencji: Marta Drabkowska-Skarba, Uniwersytet Mikołaja Kopernika w Toruniu, Wydział Nauk Ekonomicznych i Zarządzania, ul. Gagarina 13a, 87-100 Toruń, e-mail: m.skarbi89@gmail.com. 
klientów, dla których nie liczy się już tylko sam produkt, ale także pozasprzedażowe działania, mające wpływ na przykład na dobro pracowników. Tak więc, pojawienie się koncepcji Corporate Socal Responsibility skłania firmy na całym świecie do jej stosowania. Jednak w różnych przedsiębiorstwach z jednej branży widoczne są znaczące różnice w poziomie zaawansowania w tej kwestii. Nasuwa się więc pytanie, czy stosowanie koncepcji społecznej odpowiedzialności biznesu rzeczywiście kreuje bardziej prospołeczne i proodpowiedzialne przedsiębiorstwa? Czy jest tylko chwytem marketingowo-PR-owym, mającym na celu zwrócenie uwagi klientów? Celem niniejszego artykułu jest odpowiedź na te pytania oraz odzwierciedlenie rzeczywistości poprzez studium przypadku w brytyjskim przedsiębiorstwie Next plc. Pogłębione analizy jednostkowe mają za zadanie ukazać, które z propagowanych przez przedsiębiorstwa elementów etycznego biznesu są rzeczywiście stosowane.

\section{POWODY I PRZYKŁADY WPROWADZANIA ORAZ ISTOTA KONCEPCJI BIZNESU SPOŁECZNIE ODPOWIEDZIALNEGO}

Obecnie wszystkie przedsiębiorstwa mają trudną do przejścia drogę, jeśli chcą zdobyć nowych klientów i utrzymać tych, których już pozyskali. W związku z tym prześcigają się w uwzględnianiu społecznych skutków swoich działań. W XXI w. prowadzenie przedsiębiorstwa, zwłaszcza na dużą skalę, wymaga oprócz stosowania się do obowiązującego prawa i norm, między innymi przestrzegania zasad dbania o środowisko oraz zaspokajania potrzeb i oczekiwań wszystkich osób związanych z firmą. Z tym właśnie wiąże się idea Biznesu Społecznie Odpowiedzialnego.

Nie jest ona pojęciem nowym, jednak od niedawna znacznie zyskała na wartości, a powodów, dla których tak się stało, jest wiele. Po pierwsze, dzisiejszy biznes jest nacechowany znaczną niepewnością, a ze strony klientów brakiem zaufania. Wiąże się to z czasami, kiedy zdobycie ogromnych pieniędzy nie hamowało przedsiębiorców przed różnego typu matactwami. Dlatego w dobie braku zaufania ze strony społeczeństwa firmy obowiązkowo muszą zwracać uwagę na konsekwencje społeczne swoich kroków [Jasikowska 2011, s. 20]. Dodatkowo dzisiejsi klienci są znacznie bardziej wymagający od tych sprzed kilkunastu lat. Nie liczy się dla nich już tylko produkt, ale na przykład to, gdzie jest on produkowany, czy producent nie zanieczyszcza środowiska, a pracownicy nie są wyko- 
rzystywani. Dzisiejszy klient potrzebuje więc zaspokojenia także wartości psychospołecznych [Grzanka 2010, s. 104]. W związku z tym nasuwa się pytanie, czy może dobrą drogą nie byłoby zastosowanie starych zasad, takich jak uczciwość i skromność, czyli zasad etycznego biznesu [Panek-Owsiańska, 2008]? Stosowanie przez firmę koncepcji biznesu społecznie odpowiedzialnego może objawiać się również przeznaczaniem części zysków na działalność charytatywną. W tym względzie poszukiwanie informacji na temat polskich przedsiębiorstw jest zadaniem dość żmudnym i przynoszącym marne efekty. Dużo lepiej wyglądają tutaj firmy zagraniczne, które są już zapewne bardziej świadome korzyści, jakie wynikają z tego typu działań. Część klientów, wrażliwych na przestrzeganie zasad etycznych, zwracać będzie uwagę na to, czy przedsiębiorstwo jest filantropem. To właśnie poniekąd potrzeby nabywców skłaniają do tego typu zachowań. Trudno jednak nie zauważyć, że część datków charytatywnych, szczególnie na Zachodzie, nie wiąże się z Corporate Social Responsibility, ale jest zwykłym trikiem pozwalającym na przykład na zapłacenie niższych podatków. Z punktu widzenia przedsiębiorstwa jest to możliwość zaprezentowania w materiałach marketingowych dobrej woli i stosowania etycznego biznesu. Tylko czy deklarowanie przez firmę jednego, a robienie drugiego jest etyczne? Odpowiedź jest prosta i nie wymaga dogłębnej analizy.

Dbanie o środowisko jako element stosowania CSR-u również może okazać się kwestią problemową. Są oczywiście przedsiębiorstwa, które robią to, bo uważają za słuszne. Jednak podobnie jak w poprzednim przykładzie są i tacy, którzy zmuszeni do przestrzegania pewnych norm, realizują założone plany tak, by złagodzić złe postrzeganie przez opinię publiczną.

Pojawia się więc pytanie, czy Społeczna Odpowiedzialność Biznesu nie jest w wielu przypadkach tylko głoszoną wszem i wobec ideą, która ma za zadanie przyciągnięcie większego grona odbiorców towarów i usług? W dzisiejszych czasach ludzie obserwowani z każdej strony przez liczne organizacje, ale także inne osoby zwracające uwagę, kto kupuje u nieodpowiedzialnego dostawcy, mogą obawiać się bycia posądzonym o wspieranie nieetycznych praktyk. Znany jest przecież niejeden przypadek, kiedy to przedsiębiorstwo poniżające pracowników i niedające im odpowiednich warunków pracy z dnia na dzień traci klientów.

Podkreślić należy również bardzo ważny element Corporate Social Responsibility, jakim jest utrzymywanie pozytywnych relacji z innymi interesariuszami firmy. Zaufanie w biznesie jest niezwykle istotnym elementem, 
bo tworzy długotrwałe więzi między poszczególnymi podmiotami [Handy 1995, s. 41-46].

Społeczna Odpowiedzialność Biznesu ma również za zadanie pogodzenie celów krótkookresowych przedsiębiorstw z celami długookresowymi społeczeństwa, w jakim firma funkcjonuje. Oczywiście najważniejszym założeniem dla przedsiębiorstwa jest osiągnięcie jak najwyższego zysku. Jednak czy zawsze da się to pogodzić z zadowoleniem wszystkich pracowników, używaniem najwyższej jakości materiałów czy stosowaniem się do wszelkich norm środowiskowych? Zapewne niektóre firmy, szczególnie te wytwarzające produkty markowe, potrafią połączyć wszystkie te cele i z łatwością je realizować. Jednak w sytuacji, gdy produkowana jest na przykład odzież, częstym procederem jest przenoszenie produkcji do Chin, gdzie koszty pracy są o wiele niższe. Na polskim rynku zwrócić uwagę można chociażby na największego producenta odzieży - firmę LPP S.A., która w zeszłym roku przeniosła swoją siedzibę na Cypr i do Zjednoczonych Emiratów Arabskich. Dzięki takiemu krokowi przedsiębiorstwo, które w 2013 r. było szóstym co do wielkości podatnikiem w Polsce, będzie płaciło o wiele niższe podatki [http://biznes.onet.pl/lpp-przenosi-swojemarki-na-cypr-w-sieci-zawrzalo,18490,5596486,news-detal]. Co jednak z odpowiedzialnością społeczną? Ów temat spowodował bojkot marek LPP w mediach społecznościowych, gdzie swoje niezadowolenie wyraziło wielu klientów.

\section{RAPORTY SPOŁECZNEJ ODPOWIEDZIALNOŚCI BIZNESU PRZEDSIĘBIORSTWA NEXT PLC A RZECZYWISTOŚĆ}

W świetle wielu sytuacji przedstawiających niekorzystnie branżę odzieżową, podkreślających nieuczciwe praktyki zatrudnieniowe i produkcyjne oraz negatywny wpływ na środowisko, przedsiębiorstwa skupiają swoją uwagę na stworzeniu bardziej pozytywnego obrazu swojej działalności. Tworzą coraz to nowe strategie mające na celu zniwelowanie niepochlebnego obrazu rzeczywistości. Coraz więcej firm zmaga się z walką z licznymi organizacjami, stowarzyszeniami i związkami negującymi ich działalność. Na to wszystko wpływ mają wydarzenia, które pokazują, że rzeczywiście nie jest dobrze. Za przykład może posłużyć tragedia sprzed dwóch lat w fabryce Tazreen Fashion w Dakce, gdzie życie straciło ponad 120 osób, a rannych zostało ponad 300 pracowników szyjących ubrania dla znanych marek odzieży [http://cleanclothes.pl/a1197_druga_rocznica_ 
katastrofy_tazreen_ofiary_otrzymaja_wrzeszcie_odszkodowania.html\#. VNI_Ie6Xqnw], czy podobna sytuacja z 2013 r. z hali produkcyjnej Rana Plaza w Bangladeszu, gdzie zginęło ponad 1100 osób [https://payup.cleanclothes.org/a-dark-day-for-fashion/]. Takie wydarzenia niejako zmuszają przedsiębiorstwa do ocieplania wizerunku i pokazywania się z dobrej, etycznej strony. Niezwykle ciekawym przypadkiem - wartym analizy - jest przypadek przedsiębiorstwa Next plc., które corocznie na swojej stronie internetowej przedstawia raporty CSR opisujące działania podjęte przez firmę w zakresie relacji z interesariuszami, ochrony środowiska oraz procesów produkcyjnych. Przeglądając raporty Nexta z 5 ostatnich lat, można odnieść wrażenie, że opierają się one na pewnym wzorcu, według którego uzupełniane są dane. Nietrudno można zdać sobie sprawę z faktu, że raport upowszechniony w styczniu 2014 r. jest niemal odwzorowaniem raportu z 2010 r., różnią się w nim tylko niektóre dane liczbowe. Warto więc przyjrzeć się poszczególnym elementom bliżej, porównać je i sprawdzić, czy rzeczywiście można je nazwać chlubą CSR-ową przedsiębiorstwa.

Raporty przedsiębiorstwa Next plc. podzielone są na pięć głównych obszarów dotyczących społecznej odpowiedzialności biznesu, a mianowicie: klientów i produkty (customers and products), pracowników (our people), środowisko (environment), społeczność lokalną (community) oraz dostawców (suppliers). Każdy z tych elementów jest opisany na kilku bądź kilkunastu stronach, gdzie podane są wszelakie szczegóły działań, jakie firma wykonuje w zakresie CSR [http://ir2.flife.de/data/next/igb_html/index. php?bericht_id=1000010\&lang=ENG].

Do priorytetów etycznych Next zalicza przede wszystkim jakość swoich produktów, bezpieczeństwo ich użytkowania, produkcję zgodną z prawem oraz pozyskiwanie materiałów w sposób odpowiedzialny. Założeniem dla przedsiębiorstwa jest również współpraca z organizacjami rządowymi oraz pozarządowymi w zakresie społecznej odpowiedzialności. Ważnym elementem jest również aktywny program kooperacji z klientami, mający przy użyciu ankiet i wywiadów pomóc w rozwiązywaniu problemów na linii przedsiębiorstwo-klient. Wszystkie ogólne informacje dotyczące społecznej odpowiedzialności biznesu są szeroko opisane w raportach. Czytelnikowi sięgającemu po raport z danego roku społeczna odpowiedzialność biznesu stosowana przez Next jawi się w superlatywach, poświadczona jest też niezliczoną liczbą przykładów. Jak jest jednak w rzeczywistości? Już pierwszym zastanawiającym faktem jest to, że kiedy porównuje się raporty z kilku lat, można odnieść wrażenie, że zostały one powielone, a zmianom ulegają jedynie niektóre liczby. Czasem pojedyncze słowa zostały zamie- 
nione na synonimy. Dostrzegając to, warto przyjrzeć się poszczególnym elementom poruszanym w raportach, by stwierdzić, jaka jest rzeczywistość. W poniższych rozdziałach porównane zostały raporty społecznej odpowiedzialności biznesu przedsiębiorstwa Next (next corporate responsibility report) za lata 2009-2013. Dodatkowo została przeprowadzona obserwacja pięciu sklepów sieci, w tym trzech znajdujących się w Doncaster oraz dwóch w Sheffield w Wielkiej Brytanii. Obserwacja dotyczyła poszczególnych elementów opisanych $\mathrm{w}$ raportach, a jej wyniki zostaną przedstawione w poniższych rozdziałach.

\section{PRODUKTY I KLIENCI PRZEDSIĘBIORSTWA NEXT W ŚWIETLE SPOŁECZNEJ ODPOWIEDZIALNOŚCI BIZNESU}

Rozdział raportu poświęcony produktom i klientom przedsiębiorstwa pokazuje, że firma od kilku lat ma coraz większą rzeszę nabywców produktów, a co za tym idzie, coraz więcej osób zwracających uwagę na to, w jaki sposób postępuje. Powiększająca się liczba klientów widoczna jest chociażby w ilości kontaktów telefonicznych i mailowych, która w 2009 r. wynosiła $10 \mathrm{mln}$, natomiast w 2013 aż $19 \mathrm{mln}$ [http://ir2.flife.de/data/next/igb_html/ index.php?bericht_id=1000010\&lang=ENG]. Nietrudno zauważyć, że przez 5 lat liczba ta prawie się podwoiła. W świetle takich zmian wszystkie produkty przedsiębiorstwa muszą być dopasowane do jak największej liczby osób oraz odpowiadać na gusta i potrzeby ludzi w różnym wieku, $\mathrm{z}$ różnymi doświadczeniami i przekonaniami. W tym celu uruchomiony został wspomniany w poprzednim rozdziale specjalny program wydawania opinii przez klientów, który ma służyć ulepszeniu wszystkich produktów i obsługi klienta.

Przedsiębiorstwo deklaruje również dbałość o to, by wszelkie materiały używane do produkcji były nieszkodliwe dla ludzi. Zastosowane zostały również limity substancji chemicznych na poszczególne towary, które sprawdzane są przez comiesięczne specjalistyczne audyty laboratoryjne. W tej kwestii niezwykle ważne są zalecenia ekspertów, normy ekologiczne zawarte w prawie oraz opinie klientów. Czy jest jednak rzeczywiście tak, że klienci mogą wyrażać opinie w przypadkach, kiedy mają zastrzeżenia do jakiegokolwiek produktu. W jednym z salonów sprzedaży ekspedientce zadane zostało pytanie, czy można gdzieś zgłosić uwagę dotyczącą powstania zmian skórnych po użyciu jednego z zakupionych kosmetyków. Rze- 
czywiście wykazane zostało zainteresowanie, pojawiły się pytania dotyczące tego, jaki to kosmetyk, jakie były objawy oraz zapewnienie zgłoszenia tego faktu w odpowiednie miejsce. Klient może jednak nie być w takim przypadku do końca usatysfakcjonowany, ponieważ nie ma pewności, czy informacja została przekazana dalej, czy żywne zainteresowanie miało jedynie charakter marketingowy.

Next deklaruje również $\mathrm{w}$ raporcie monitorowanie produkcji, ocenę szkód, jakie tworzenie produktów może spowodować na środowisku, oraz zakazy stosowania materiałów z nielegalnych źródeł. Zagadnienia te jednak trudno zweryfikować na podstawie obserwacji. Przedsiębiorstwo pisze także o możliwości sprawdzenia przez klienta obecności szkodliwych substancji w towarach. Jeśli zostałby złożony tego typu wniosek, korporacja ma 45 dni na sprawdzenie takich spekulacji. W 2013 oraz 2012 roku nie było takich postulatów. We wcześniejszych badanych latach brak jest informacji na ten temat.

W raportach bardzo podkreślane jest bezpieczeństwo dzieci. Przedsiębiorstwo jest nawet członkiem grup roboczych British Standard Institution oraz European Comitee for Standarization [http://www.nextplc.co.uk/ / media/Files/N/Next-PLC/pdfs/corporate-responsibility-report/cr-2014.pdf] odpowiedzialnych za tworzenie standardów w tym zakresie. W żadnym z raportów nie wymieniono jednak konkretnych działań, które byłyby zaproponowane bezpośrednio przez Next. Tutaj po raz kolejny rodzi się pytanie, czy członkostwo rzeczywiście przekłada się na konkretne akcje, czy niekoniecznie?

Dokumenty z poszczególnych lat opisują nie tylko praktyki etyczne zapobiegawcze, ale także takie, które odpowiadają na sytuacje, które już się wydarzyły. Jedną z nich może być taka, kiedy jakiś produkt okaże się niebezpiecznym dla klientów bądź środowiska. Koncern w takiej sytuacji postępuje według poniższych zasad [http://www.nextplc.co.uk/ /media/Files/N/Next-PLC/pdfs/corporate-responsibility-report/cr-2014.pdf]:

- ,zamrożenie” niebezpiecznych towarów w magazynach, bez możliwości ich transportu do sieci sprzedaży,

- usunięcie towarów z sal sprzedaży,

- poinformowanie klientów, którzy zakupili niebezpieczny produkt o sytuacji oraz refundacja kosztów,

- utylizacja towarów.

Fakt posiadania procedury postępowania na wypadek powstania niebezpieczeństwa jest zacny, jednak czym tak naprawdę są niebezpieczne produkty? Czy w swoim składzie mają materiały pochodzące z nielegal- 
nych źródeł? Czy też takie, które zawierają substancje chemiczne bądź na przykład te, dla których zabija się zwierzęta? Informacji na ten temat w raporcie nie uzyskamy. Może należałoby zatem obejrzeć dokładnie wszystkie metki, ponieważ przedsiębiorstwo deklaruje, że w 2009 r. dokonało przeglądu wszystkich opakowań i oznaczyło produkty, w których gdziekolwiek pojawiły się substancje niebezpieczne. Nie wiadomo jednak, czy po tym czasie była jeszcze jakaś aktualizacja, czy ta sprzed kilku lat była jednorazowym sprawdzeniem.

Jednym z elementów najszerzej poruszonych w odniesieniu do produktów w raportach CSR przedsiębiorstwa Next jest pochodzenie materiałów. Analizując sprawozdania z poszczególnych lat, można się dowiedzieć, że w 2010 r. korporacja ustanowiła, że wszystkie surowce, z których tworzone są produkty, będą pozyskiwane odpowiedzialnie. Inicjatywa ta weszła jednak w życie dopiero w 2013 r. Co działo się w międzyczasie? Tego nie wiadomo.

Jednym z surowców, który budzi wiele kontrowersji nie tylko wśród ekologów, jest drewno. W tym aspekcie rzeczywiście widać pewne różnice w raportach z poszczególnych lat. Można więc uznać, że firma podejmuje pewne kroki w tym względzie. Zainteresowanie sprawą drewna rozpoczęło się w 2010 r., kiedy to Next wydał certyfikat, że wszystkie jego meble ogrodowe zostały wyprodukowane $\mathrm{z}$ drewna pochodzącego z legalnego źródła. Rok 2011 przyniósł ze sobą kolejne certyfikaty wydane przez Forest Stewardship Council dla ponad 2,5 mln produktów. W następnym roku korporacja wymagała już od swoich dostawców drewna potwierdzenia, skąd pochodzą materiały, a co za tym idzie, wyprodukowała 5,9 mln artykułów stworzonych $\mathrm{z}$ drewna $\mathrm{z}$ legalnej wycinki i dobrze zarządzanych lasów [http://www.nextplc.co.uk/ /media/Files/N/Next-PLC/pdfs/corporate-responsibility-report/cr-2013-v2.pdf]. Przyglądając się ostatniemu aspektowi, można odnieść wrażenie, że odpowiedzialność za produkcję drewnianych rzeczy przedsiębiorstwo scedowało na dostawców, ponieważ to oni potwierdzają źródło pochodzenia drewna. Co by się stało w sytuacji, gdyby okazało się, że jeden z produktów drewnianych opisany jako społecznie odpowiedzialny i wyprodukowany z materiałów pochodzących z legalnej wycinki jednak takim nie był? Założyć można, że jeden z dostawców rzeczywiście poświadczył to, o co prosił go odbiorca, ale w rzeczywistości przyczynił się do bezprawnego wyrębu lasu. Next w takiej sytuacji ma potwierdzenie, że nie przyczynił się do niszczenia środowiska naturalnego, ponieważ zawierzył swojemu dostawcy. Tak więc zastosowanie wymogu certyfikatów to strategicznie mądre rozwiązanie, które jednak nie do koń- 
ca przekłada się na deklarowaną odpowiedzialność. 2013 r. nie przyniósł w kwestii drewna żadnych nowych rozwiązań, nadal dostawcy potwierdzają legalność źródeł, a przedsiębiorstwo to potwierdza, zawierzając na słowo.

Niezwykle istotne inicjatywy pojawiają się również w zakresie produktów pochodzenia zwierzęcego. Już kolekcja jesienna 2009/2010 opatrzona była metkami potwierdzającymi nieużywanie prawdziwych futer i zastępowanie ich tak zwanymi ,artifical fur”, czyli futrami sztucznymi. [http://www.nextplc.co.uk/ /media/Files/N/Next-PLC/pdfs/corporate-responsibility-report/cr-2014.pdf]. Idea jest taka, że mają być bardzo realistyczne i przypominać swym wyglądem futra naturalne. Potwierdzeniem tego, że Next sprzedaje tylko futra sztuczne, jest fakt umieszczenia go na liście przedsiębiorstw niesprzedających futer naturalnych. Taka lista została stworzona przez Fur Free Alliance i została opublikowana na stronie www. furfreeretailer.com.

W 2013 r. liczne przedsiębiorstwa produkujące odzież zostały oskarżone o korzystanie z futer królików angora pochodzących z ferm w Chinach, które są uznane za najbardziej nieprzestrzegające praw zwierząt [http:// www.theguardian.com/world/shortcuts/2013/dec/16/angora-productionethical-peta-video-chinese-rabbits]. W Internecie znaleźć można wiele przerażających zdjęć i filmów pokazujących tamtejsze fermy, gdzie uśmierca się zwierzęta, rzucając je o mur, dusząc lub uderzając w głowę. Pojawiają się również przypadki skalpowania żywych zwierząt [Płonka 2013, s. 66-77]. Po tym incydencie Next wysłał audytorów do ferm w Chinach dostarczających futer $\mathrm{z}$ angory dla przedsiębiorstwa. Tutaj od razu nasuwa się pytanie. Po co przedsiębiorstwo podjęło w bardzo krótkim czasie takie kroki, skoro już w 2009 r. zadeklarowało, że nie używa futer naturalnych? Kwestia z pewnością nasuwa pewne domysły i podejrzenia. Zwłaszcza że dopiero po tej sytuacji został wprowadzony zakaz używania angory w całej działalności. Czy więc na przykład swetry z angory nie były traktowane jako produkt stworzony z futra? Nie jest to nigdzie opisane, jednak po raz kolejny rodzi się wątpliwości, czy królik i na przykład norka są zwierzętami różnych kategorii, a produkty z ich futer traktuje się zgoła inaczej? Chodzić może o to, że angorę z futerka królika można ostrzyc bez robienia mu jakiejkolwiek krzywdy, natomiast do produkcji futrzanych płaszczy czy kurtek inne zwierzęta, takie jak lisy, norki, jenoty, trzeba zabić. Jak pokazuje jednak praktyka, na wielu fermach nawet angory są zabijane, ponieważ tak można taniej i szybciej uzyskać „materiał”, którego się potrzebuje. Warto zaznaczyć, że Next jest przykładem przedsiębiorstwa, które co 
prawda używało powyżej opisywanej angory, ale zarzekało się stosowania innych futer. Jest jednak bardzo wiele korporacji, które produkują z nich swoje ubrania, czego skalę można zobaczyć w liczbach. W 2001 r. wartość sprzedaży futer na całym świecie wynosiła 11 miliardów dolarów [http:// www.dailymail.co.uk/femail/article-1366983/How-ethical-fur-fashion-industrys-cynical-yet.html\#axzz2KPKQSLaN]. W samej Unii Europejskiej w 2003 r. - 4,56 miliarda dolarów. Podczas jednego targu, na którym można kupić futra w Chinach, sprzedaje się nawet 1,8 miliona skalpów zwierząt [Płonka 2013, s. 67-69].

Powracając do Nexta, warto zwrócić uwagę, że już w 2010 r. przedsiębiorstwo rozpoczęło współpracę z British Retail Consortium i z Royal Society for the Prevention of Cruelty to Animals w ramach sprzeciwiania się mulesingowi w australijskim przemyśle wełnianym [http://www.nextplc.co.uk/ /media/Files/N/Next-PLC/pdfs/corporate-responsibility-report/ Corporate\%20responsibility\%202011\%20FINAL.pdf]. Proces ten polega na wycinaniu tych elementów skóry owiec, które są podatne na wszelkiego rodzaju stany zapalne oraz stanowią miejsce lęgowe dla insektów. Wszystko byłoby w jak najlepszym porządku, gdyby nie to, że między innymi w Australii zgodne z prawem jest wycinanie owych części skóry zazwyczaj wraz z żywymi fragmentami bez jakichkolwiek znieczulaczy. Dodatkowo, nie ma do tych czynności przeznaczonych żadnych specjalnych narzędzi. Farmerzy stosują w tym celu albo nożyce ogrodnicze, albo inne narzędzia pozwalające swoją konstrukcją na takie zabiegi [Płonka 2013, s. 57]. Tutaj ponownie pojawia się niepokój związany z tym, że przedsiębiorstwo deklarujące zakaz używania futer może zgadzać się na wykorzystywanie wełny, której pozyskiwanie również okalecza zwierzęta i w wielu przypadkach skazuje je na śmierć. W 2010 r. Next zaczął sprawdzać miejsca pochodzenia wełny, której używa przy wyrobie swoich towarów. Można mieć jedynie nadzieję, że rzeczywiście tak jest, że większe zarobki na tańszej wełnie pozyskiwanej na farmach, gdzie stosuje się mulesing, nie przysłonią idei ochrony zwierząt.

Kolejną niezwykle istotną sprawą, na którą mogą zwrócić uwagę obrońcy zwierząt, jest produkcja galanterii ze skóry. Co prawda w raportach nie ma na ten temat żadnej wzmianki, jednak kiedy udamy się do salonu sprzedaży, to na pierwszy rzut oka znaleźć możemy co najmniej kilka artykułów z oznaczeniem ,genuine leather”. Podobnie jak w przypadku futer, produkowanie przedmiotów ze skór zwierząt może budzić kontrowersje, czy jest to do końca etyczne. Zapewne odpowiedź zależy od stanowiska, jakie zajmuje dana osoba w stosunku do towarów pochodzenia odzwierzęcego, 
natomiast $\mathrm{z}$ pewnością informacja o tym powinna być ujęta $\mathrm{w}$ raportach dotyczących społecznej odpowiedzialności biznesu. A korporacja, która propaguje ideę używania sztucznych futer i pomoc organizacjom dążących do dobrego traktowania zwierząt, powinna zabrać głos w tej sprawie. Czy dane dotyczące produkcji torebek, pasków czy portfeli skórzanych została pominięta celowo, czy uznano je za zbyt mało ważne? Tego również można się jedynie domyślać.

Inną ważną sprawą związaną z ochroną zwierząt jest testowanie na nich różnych produktów, w szczególności kosmetyków. Badane przedsiębiorstwo deklaruje, że nie testuje produktów kosmetycznych na zwierzętach. Ponadto wspiera fundację Fund for the Replacement of Animals in Medical Experimentatial, która promuje już wykorzystywane i szuka nowych metod laboratoryjnych, dzięki którym towary nie muszą być testowane ani na zwierzętach, ani na ludziach [http://www.frame.org.uk]. Dla sprawdzenia autentyczności informacji o braku testów na zwierzętach przeanalizowane zostały opakowania wszystkich kosmetyków znajdujących się na półkach sklepowych Nexta w marcu 2015 r. Niestety, odnaleziony został odświeżacz powietrza do pomieszczeń, na którym takowa informacja się nie znalazła. Dla porównania na innych odświeżaczach widniało logo potwierdzające brak omawianych testów. Ciekawostką może być to, że wspomniany odświeżacz jako jedyny został wyprodukowany w Chinach. Czy to zbieg okoliczności, czy może błąd projektanta opakowania, który zapomniał o dodaniu tak istotnej informacji? Należy mieć nadzieję, że to drugie.

Wszystkie powyższe przykłady pokazują, że wiele zachowań przedsiębiorstw z zakresu społecznej odpowiedzialności biznesu budzi wątpliwości. Są one zacne i wyglądają pozytywnie tylko na pierwszy rzut oka, jednak po dogłębniejszym przeanalizowaniu widać w nich wiele uchybień. Z punktu widzenia zarządzających firmą elementy, które mają dobry wpływ na zwiększenie sprzedaży, są pozytywnymi technikami sprzedażowo-marketingowymi. Inaczej jednak wygląda to ze strony klienta. Czy może on poczuć się oszukiwany i manipulowany? Z pewnością tak. Może jednak jest tak, że dla kupujących najważniejsza jest cena i jakość ubrania, a wszystko inne nie ma znaczenia? Jest to z pewnością ciekawe pytanie do dalszych badań. 


\section{PRACOWNICY - NAJWAŻNIEJSZY ZASÓB PRZEDSIĘBIORSTWA}

Kolejnym dużym podrozdziałem raportów społecznej odpowiedzialności biznesu przedsiębiorstwa Next jest część dotycząca pracowników. Chodzi tutaj o wszystkich pracowników - zarówno sprzedażowych, których codziennym miejscem pracy są sklepy, jak i tych zatrudnionych w magazynach, administracji czy halach produkcyjnych. Odpowiedzialność w tym zakresie Next rozumie jako stworzenie środowiska zatrudnienia, które zachęca ludzi do pracy i jest zarazem bezpieczne [http:/www.nextplc. co.uk/ /media/Files/N/Next-PLC/pdfs/corporate-responsibility-report/ cr-2014.pdf]. Podkreślanymi przez firmę na każdym kroku elementami są uczciwość, szacunek, zachęta i możliwości rozwoju. Przedsiębiorstwo stworzyło wewnętrzny kodeks postępowania wobec pracowników, którego składowymi są [http://www.nextplc.co.uk / /media/Files/N/Next-PLC/ pdfs/corporate-responsibility-report/cr-2014.pdf]:

- wspieranie i szanowanie pracowników,

- sprawiedliwe traktowanie i dbałość o ich interesy,

- słuchanie pracowników,

- motywowanie do pełnego wykorzystania własnego potencjału.

Wszystkie te detale ujęte są $\mathrm{w}$ raportach $\mathrm{z}$ poszczególnych lat obok podstawowego przestrzegania praw człowieka oraz zakazu dyskryminacji. W tej ostatniej kwestii korporacja deklaruje, że zatrudnia osoby niepełnosprawne. Co prawda nie jest to widoczne na podstawowym szczeblu, czyli w salonach sprzedażowych, jednak warto takim deklaracjom zawierzyć. Ponadto w przedsiębiorstwie widoczna jest równość szans i dywersyfikacja, jeśli chodzi o płeć zatrudnionych pracowników. Na przykład w 2013 r. na stanowiskach dyrektorskich zatrudnione były 3 kobiety, a menadżerowie wyższego szczebla to w tym roku w 13 przypadkach kobiety. Rok wcześniej 2 kobiety pracowały na stanowiskach dyrektorskich, a 17 wchodziło w skład managementu wyższej rangi. W raportach nie ma zawartych informacji co do poprzednich lat. Zagadnienie równości kobiet i mężczyzn w kwestiach zatrudnieniowych odgrywa ważną rolę w dzisiejszym zarządzaniu i jest sprawą bardzo często poruszaną. Jest również bardzo często włączane w strategie CSR, będąc elementem działań związanych ze sprawiedliwym podejściem do pracowników [http://www.2becsr.eu/index. php?option=com_content\&view $=$ article\&id $=17$ :czy-kwestie-rownosci-plc i-moga-byc-wlaczone-w-strategie-csr\&catid=20\&Itemid=125]. 
W raportach wiele uwagi skupiono na bezpieczeństwie pracy. W Next prowadzony jest rejestr wypadków lub niebezpiecznych zdarzeń, tzw. RIDDOR ( $\mathrm{z}$ ang. The Reporting od Injuries, Diseases and Dangerous Occurrences Regulations). Według niego najwięcej wypadków w całym przedsiębiorstwie wydarzyło się w czterech głównych zakresach [http://www. nextplc.co.uk/ /media/Files/N/Next-PLC/pdfs/corporate-responsibility-report/cr-2014.pdf]:

- poślizgnięcie, potknięcie,

- podnoszenie, wieszanie, układanie,

- kontakt ze stałymi elementami (np. wystroju, maszynami),

- kontakt ze spadającymi bądź poruszającymi się przedmiotami.

Wypadki poprzez poślizgnięcie bądź potknięcie osiągnęły swój maksymalny poziom $\mathrm{w}$ pierwszym oraz ostatnim $\mathrm{z}$ analizowanych lat. $\mathrm{W}$ tym zakresie raczej trudno o eliminację tego typu zdarzeń, gdyż powodów tego może być wiele. $Z$ jednej strony można mieć do czynienia z niewłaściwym obuwiem pracowników, które powoduje poślizgnięcia, z drugiej zaś strony podłoga może być wykonana z materiałów, które powodują łatwość przewrócenia się. Liczbę wypadków w tym zakresie przedstawia poniższy wykres.

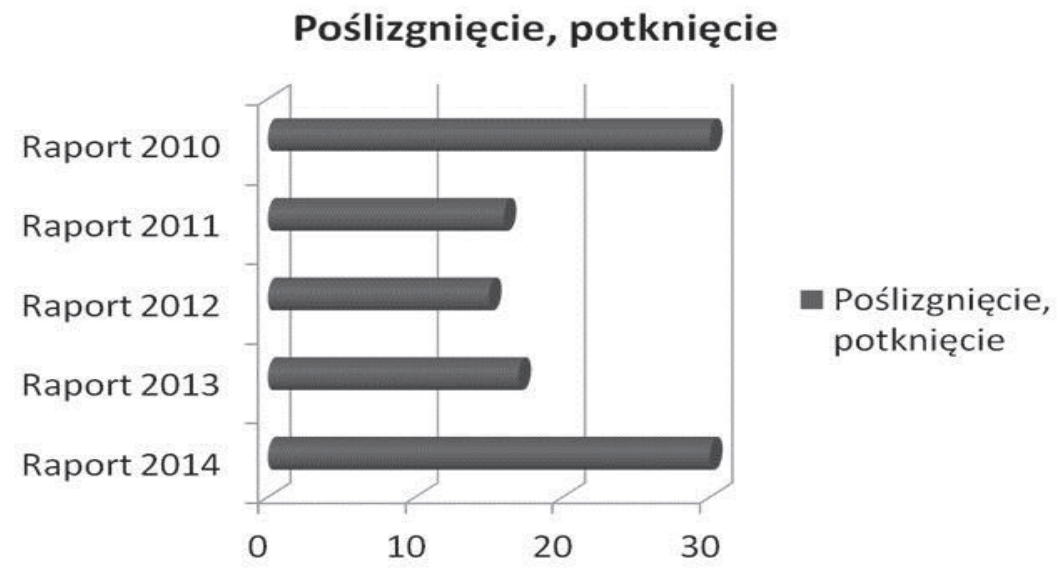

Wykres 1. Liczba wypadków spowodowana poślizgnięciem lub potknięciem w poszczególnych latach

Źródło: opracowanie własne na podstawie raportów społecznej odpowiedzialności biznesu przedsiębiorstwa Next plc z poszczególnych lat [http://www.nextplc. co.uk/corporate-responsibility/corporate-reports.aspx]. 
Drugie częste niebezpieczeństwo, na jakie narażeni są pracownicy Nexta, to podnoszenie, wieszanie lub układanie. Trudno tutaj również powiedzieć o sposobach, w jakich przedsiębiorstwo mogłoby wyeliminować tego typu zagrożenia. Jednym ze sposobów, jaki się nasuwa, jest szkolenie pracowników i przygotowanie ich do tego typu pracy, do tego, w jaki sposób radzić sobie z zadaniami, by nie stały się one ryzykiem. Poniżej widoczna jest liczba omawianych wypadków w poszczególnych latach, z czego jasno wynika, że jest to zjawisko trudne do wykluczenia.

\section{Podnoszenie, wieszanie, układanie}



Wykres 2. Liczba wypadków w poszczególnych latach spowodowana podnoszeniem, wieszaniem lub układaniem niesprecyzowanych rzeczy

Źródło: opracowanie własne na podstawie raportów społecznej odpowiedzialności biznesu przedsiębiorstwa Next plc z poszczególnych lat [http://www.nextplc. co.uk/corporate-responsibility/corporate-reports.aspx].

Trzecim najczęstszym powodem wypadków przy pracy w Next są efekty uderzeń spadających bądź poruszających się przedmiotów. Zjawisko wydawałoby się łatwe do wykluczenia, które w zasadzie po jednym przypadku powinno być wyeliminowane. W omawianym przedsiębiorstwie tak się jednak nie dzieje. Jak widać na poniższym wykresie, liczba podobnych sytuacji wzrosła w ostatnim roku w stosunku do lat wcześniejszych. Może to świadczyć o braku podjęcia jakichkolwiek kroków, by przeciwdziałać podobnym przypadkom. 


\section{Spadające, poruszające się obiekty}

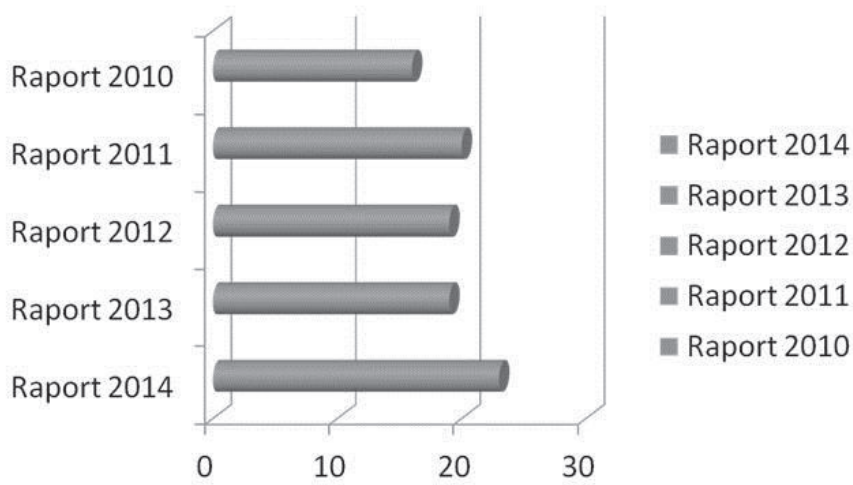

Wykres 3. Liczba wypadków w poszczególnych latach spowodowana spadaniem lub poruszaniem się przedmiotów

Źródło: opracowanie własne na podstawie raportów społecznej odpowiedzialności biznesu przedsiębiorstwa Next plc z poszczególnych lat [http://www.nextplc. co.uk/corporate-responsibility/corporate-reports.aspx].

Ostatnim źródłem najpowszechniejszych wypadków jest kontakt ze stacjonarnymi obiektami. Wychodząc z założenia, że zaliczamy do nich maszyny, elementy wyposażenia, meble, można wywnioskować, iż wszystkie te przedmioty znajdowały się w niewłaściwych miejscach. Można również doszukiwać się nieuwagi samych pracowników, którzy byli ofiarami wypadków, jednak ich liczba świadczy, że to jednak nie jest jedyny powód. W ostatnim z analizowanych lat liczba zdarzeń, o których mowa, zmalała ponaddwukrotnie, porównując do roku 2013, oraz prawie o połowę, biorąc pod uwagę lata poprzednie. Może to świadczyć o krokach, jakie zostały powzięte, aby zapewnić pracownikom większe bezpieczeństwo i zmniejszyć wskaźnik RIDDOR. 


\section{Kontakt ze stojącymi obiektami} (uderzenia)

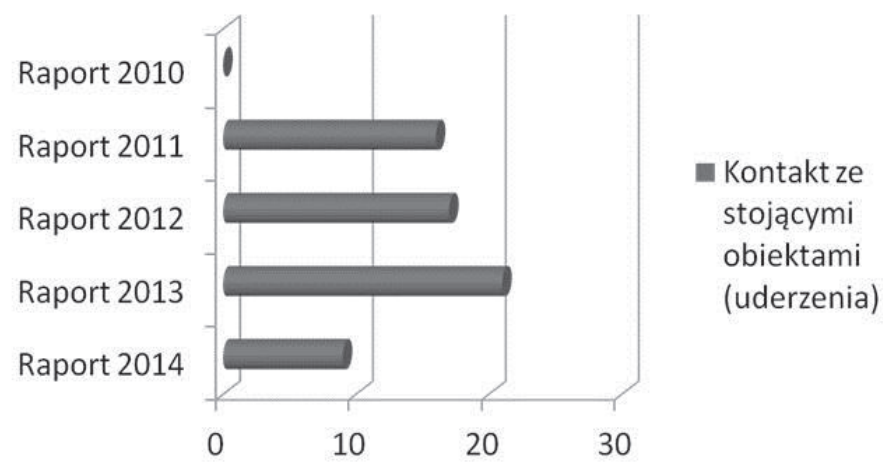

Wykres 4. Liczba wypadków w latach 2010-2014 spowodowana kontaktem z ustawionymi na stałe obiektami

Źródło: opracowanie własne na podstawie raportów społecznej odpowiedzialności biznesu przedsiębiorstwa Next plc z poszczególnych lat [http://www.nextplc. co.uk/corporate-responsibility/corporate-reports.aspx].

Bezpieczeństwo osób zatrudnionych w korporacji jest jednym z najważniejszych elementów wpływających na to, czy dane przedsiębiorstwo można traktować jako odpowiedzialne za swoich pracowników, czy też nie. Niezwykle istotne jest, że Next monitoruje wszelkie wypadki, jakie mają miejsce w poszczególnych departamentach. Raporty oprócz zestawień umieszczonych powyżej opisują dokładnie różnice w wysokości RIDDOR w ostatnich latach. Ważne jest to, że firma mimo insynuacji o pewnych zaniedbaniach opisanych powyżej dba o ogólne dobro pracowników. W związku z tym może pochwalić się 17\% spadkiem w 2012 r. zarówno wskaźnika RIDDOR, jak i ogólnej liczby wypadków w całym przedsiębiorstwie. 2013 r. przyniósł jeszcze lepsze wyniki w zakresie bezpieczeństwa, które przełożyć można na konkretne liczby [http://ir2.flife.de/data/next/ igb_html/index.php?bericht_id=1000010\&lang=ENG]:

- $18 \%$ zmniejszenie wartości wskaźnika RIDDOR w magazynach,

- 9\% zmniejszenie całkowitej liczby wypadków w całym przedsiębiorstwie,

- 11\% zmniejszenie wartości wskaźnika RIDDOR w regionalnych centrach usług,

- 3 wypadki w ciągu całego roku w departamentach administracyjnych. 
Liczby te odzwierciedlają zaangażowanie głównego kierownictwa w poprawę bezpieczeństwa pracowników, a co za tym idzie, ich świadomość społecznej odpowiedzialności biznesu odnoszącej się do pracowników.

Oprócz poprawy bezpieczeństwa sensu stricto Next wprowadził jeszcze wiele działań, które opisuje w swoich raportach CSR i które odnoszą się do osób zatrudnionych. Warte podkreślenia są tygodniowe i miesięczne kontrole bezpieczeństwa, które po wielu audytach wprowadziły między innymi dodatkowe elementy meblowe, mające na celu zapobieganie zranieniu się poprzez bezpośredni kontakt. Wszystkie budynki, które powstały przed 2000 r., zostały zbadane pod kątem obecności azbestu. Dla kierowców wprowadzono badania oraz szkolenia, dzięki którym ich praca stała się bezpieczniejsza, a trasy skrócono, by nie narażać na nadmierne zmęczenie. Rzadko które przedsiębiorstwo może pochwalić się tak rozbudowanymi programami nastawionymi na wsparcie pracownicze. Pod tym względem Next pokazuje, jak można być zaangażowanym w tworzenie własnej wizji społecznej odpowiedzialności przedsiębiorstwa. Martwi jedynie fakt, że wszystkie elementy pozostają niezmienne od kilku lat. Nie wprowadza się również żadnych nowych opracowań. Może to świadczyć o tym, że albo te, które istnieją, działają bez zarzutów, albo zostały one przygotowane po to, aby przedsiębiorstwo mogło pokazywać swoje zaangażowanie między innymi w omawianych raportach.

W ramach społecznej odpowiedzialności biznesu korporacja prowadzi również coroczne bezpłatne szczepienia dla pracowników. Z roku na rok z takiego pakietu korzysta coraz więcej osób. Dla porównania w 2010 r. zaszczepiło się 1980 zatrudnionych, a w 2013 r. - 2600 [http://ir2.flife. de/data/next/igb_html/index.php?bericht_id=1000010\&lang=ENG, http:// www. nextplc.co.uk/ /media/Files/N/Next-PLC/pdfs/corporate-responsibility-report/Corporate $\% 20$ responsibility $\% 202011 \% 20$ FINAL.pdf]. Warto jednak podkreślić, że szczepienia skierowane są jedynie dla osób pracujących w centrali przedsiębiorstwa. $Z$ czego to wynika? Czy mogłoby to świadczyć o tym, że są oni najbardziej zaangażowani w rozwój przedsiębiorstwa? Z pewnością nie, tak więc $\mathrm{z}$ obiektywnego punktu widzenia można uznać taką sytuację za nieco krzywdzącą dla pozostałych zatrudnionych. Mogą oni jednak skorzystać z innych benefitów przygotowanych przez kierownictwo. Poniższa tabelka przedstawia środki, jakie co roku przeznaczane są na świadczenia zdrowotne dla pracowników. 
Tabela 1. Środki przeznaczone na świadczenia zdrowotne pracowników Next w poszczególnych latach

\begin{tabular}{|c|c|}
\hline Rok & $\begin{array}{c}\text { Kwota przeznaczona } \\
\text { na świadczenia zdrowotne }\end{array}$ \\
\hline 2009 & $Ł 760000$ \\
\hline 2010 & $Ł 890000$ \\
\hline 2011 & $Ł 950000$ \\
\hline 2012 & $Ł 970000$ \\
\hline 2013 & $Ł 1000000$ \\
\hline
\end{tabular}

Źródło: opracowanie własne na podstawie raportów społecznej odpowiedzialności biznesu przedsiębiorstwa Next plc z poszczególnych lat [http://www.nextplc. co.uk/corporate-responsibility/corporate-reports.aspx].

Pieniądze te pokrywają koszty ubezpieczeń i świadczeń zdrowotnych, wsparcia i poradnictwa w zakresie zdrowia, program doradczy oraz możliwości korzystania z posiłków oraz siłowni w zakładzie pracy.

Duże zasoby poświęcane są także na pakiety szkoleń pracowniczych. W tym przypadku nie ma rozgraniczenia na pracowników w centrali i pozostałych departamentach. Oczywiście dla każdego przygotowane są różne rodzaje treningów, jednak wszyscy mogą z nich skorzystać. Jednym z przykładów jest program szkoleniowy dla kadry zarządzającej Management Development Programme, który rozpoczął się w 2010 r. W tym czasie ukończyły go 54 osoby. W kolejnych latach liczba absolwentów znacznie wzrastała, i tak w 2011 r. było ich 176, w 2012 r. - 200. Ostatni z analizowanych okresów przyniósł przedsiębiorstwu 52 pracowników z ukończonym kursem [http://www.nextplc.co.uk/corporate-responsibility/corporate-reports.aspx].

Innym niezwykle ciekawym rozwiązaniem jest stworzenie dla pracowników chcących awansować na wyższe stanowiska możliwości pracy przez określony czas u boku doświadczonego kierownika. Pozwala to pokazać ambitnym osobom, na czym konkretnie polega praca na szczeblach menadżerskich, oraz rozwiązywać rzeczywiste problemy przedsiębiorstwa wraz z zarządzającymi [http://ir2.flife.de/data/next/igb_html/index.php?bericht_ $\mathrm{id}=1000010 \&$ lang $=\mathrm{ENG}]$.

Next może pochwalić się również poprawiającymi się wskaźnikami zaangażowania pracowników. Od roku 2011 przeprowadzane są ankiety ba- 
dające zadowolenie kadry. Dodatkowo wybierani są przedstawiciele (1 na 50 pracowników), którzy uczestniczą w zebraniach managementu i mogą sugerować swoje rozwiązania pewnych kwestii [http://ir2.flife.de/data/ next/igb_html /index.php?bericht_id=1000010\&lang=ENG].

Stworzone zostały również przedszkola dla dzieci pracowników, dzięki czemu rodzice mogą wrócić do pracy bez obaw o miejsce w innych ośrodkach publicznych. Przedsiębiorstwo szczyci się również tym, że przedszkola zaoferowały dużo nowych miejsc pracy, co pozytywnie wpływa na odbiór chociażby lokalnego społeczeństwa.

Jeszcze innym przykładem angażowania się Nexta w sfery wchodzące w skład szeroko pojętej społecznej odpowiedzialności biznesu jest współpraca z 4 uniwersytetami. Poprzez różnego typu akcje, takie jak organizowanie dni otwartych, staże czy praktyki, przedsiębiorstwo nie tylko pokazuje się w oczach studentów jako potencjalny przyszły pracodawca, ale daje realne szanse zatrudnienia nawet na studiach. Przykładem może być propozycja staży, dzięki którym studenci mogą połączyć pracę zawodową z obowiązkami na uczelni, ponieważ praca zajmuje im tylko 30 godzin tygodniowo, dodatkowo elastycznie dopasowanych do zajęć akademickich [http://www.nextplc.co.uk/ /media/ Files/N/Next-PLC/pdfs/corporate-responsibility-report/cr-2014.pdf].

Wszystkie poruszone aspekty pokazują, że Next plc jest przedsiębiorstwem godnym naśladowania w wielu kwestiach pracowniczych. Rzadko która firma może pochwalić się tak szeroko rozbudowanymi pakietami socjalnymi. Działy HR z pewnością dbają o rozwój ścieżek kariery swoich pracowników i poziom satysfakcji z pracy. Patrząc pod kątem tych działań jako części społecznej odpowiedzialności biznesu, można uznać, że wykorzystane są w większości książkowe przykłady elementów CSR w zakresie pracowników.

\section{ZAKOŃCZENIE}

Podsumowując wszystkie opisane powyżej praktyki CSR-owe stosowane przez przedsiębiorstwo Next, śmiało można stwierdzić, że korporacja wykorzystuje bardzo dużo dostępnych możliwości, aby być społecznie odpowiedzialną. Biorąc analizowany przypadek za przykład, można by było sobie życzyć, by więcej przedsiębiorstw działało odpowiedzialnie w tak wielu aspektach. W toku obserwacji wykazano, że nie wszystkie deklarowane działania są wykonywane w sposób prawidłowy i całościowy, jednak 
same próby ich wykorzystywania i rozwijania są niezwykle istotne. Korzyści wynikające z zaangażowania przedsiębiorstwa przysparzają wartości dodanej nie tylko interesariuszom, ale przede wszystkim samej firmie. Przede wszystkim zyskuje ona zaangażowanych pracowników, oddanych klientów i pozytywnie nastawioną społeczność, mającą styczność z salonami sprzedaży, magazynami czy szwalniami. Dodatkowo przedsiębiorstwo nie musi obawiać się o coraz częstsze nagonki w mediach dotyczące nieetycznej produkcji, zatrudniania ludzi czy zachowań firm mających wpływ na zanieczyszczenia środowiska. W odniesieniu do innych przedsiębiorstw z branży odzieżowej Next stawia dość wysoko poprzeczkę, ponieważ rzadko zdarza się, by firma była zaangażowana w tak wiele zabiegów projakościowych w zakresie CSR. Next jest więc przypadkiem wartym analizy i obserwacji, a przede wszystkim przykładem pokazującym, że środowisko branżowe zaczyna dostrzegać kwestię etyki w modzie, a to przekłada się na etykę w całym prowadzonym biznesie.

\section{LITERATURA}

Grzanka I. (2010), Indywidualizacja relacji z klientami - ujęcie teoretyczno-praktyczne, [w:] M. Brzozowska-Woś (red.), Marketing. Ujęcie relacyjne, Politechnika Gdańska, Gdańsk.

Handy C., (1995), Trust and the virtual organization, „Harvard Business Review”, nr 37(3).

Jasikowska K. (2011), Nowy, lepszy świat? Globalizacja po korekcie, [w:] R. Karaszewski, M. Karwacka, A. Paluszek (red.), Społeczna odpowiedzialność biznesu - perspektywy i kierunki rozwoju, Wydawnictwo Naukowe Uniwersytetu Mikołaja Kopernika, Toruń.

Płonka M. (2013), Etyka w modzie czyli CSR w przemyśle odzieżowym, Em pe studio design sp. z o.o., Międzynarodowa Szkoła Kostiumografii i Projektowania Ubioru, Warszawa.

http://biznes.onet.pl/lpp-przenosi-swoje-marki-na-cypr-w-sieci-zawrzalo, 18490,5596486,news-detal

http://cleanclothes.pl/a1197_druga_rocznica_katastrofy_tazreen_ofiary_otrzymaja_wrzeszcie_odszkodowania.html\#.VNI_Ie6Xqnw

http://www.nextplc.co.uk/ /media/Files/N/Next-PLC/pdfs/corporate-responsibility-report/cr-2014.pdf

http://ir2.flife.de/data/next/igb_html/index.php?bericht_id=1000010\&lang=ENG http://www.nextplc.co.uk/corporate-responsibility/corporate-reports.aspx 
http://www.nextplc.co.uk/ /media/Files/N/Next-PLC/pdfs/corporate-responsibility-report/Corporate\%20responsibility\%202011\%20FINAL.pdf

http://www.nextplc.co.uk/ /media/Files/N/Next-PLC/pdfs/corporate-responsibility-report/cr-2014.pdf

http://www.2becsr.eu/index.php?option=com_content\&view=article\&id=17:czykwestie-rownosci-plci-moga-byc-wlaczone-w-strategie-csr\&catid=20\&Ite $\operatorname{mid}=125$

http://www.nextplc.co.uk/ /media/Files/N/Next-PLC/pdfs/corporate-responsibility-report/cr-2013-v2.pdf

http://www.furfreeretailer.com/index.php

http://www.theguardian.com/world/shortcuts/2013/dec/16/angora-productionethical-peta-video-chinese-rabbits

http://www.dailymail.co.uk/femail/article-1366983/How-ethical-fur-fashion-industrys-cynical-yet.html\#axzz2KPKQSLaN

http://www.nextplc.co.uk/ /media/Files/N/Next-PLC/pdfs/corporate-responsibility-report/Corporate $\% 20$ responsibility\%202011\%20FINAL.pdf

http://www.frame.org.uk

http://www.2becsr.eu/index.php?option=com_content\&view=article\&id=17:czykwestie-rownosci-plci-moga-byc-wlaczone-w-strategie-csr\&catid=20\&Ite $\operatorname{mid}=125$

\title{
CORPORATE SOCIAL RESPONSIBILITY OR SPECIAL MARKETING ACTIONS? - CASE STUDY OF NEXT PLC
}

\begin{abstract}
The article presents a case study of company Next plc in the light of corporate social responsibility. Author focused on the three resources- customers, employees and products. Nowadays, the koncept of CSR is an important element of business. Multitude of behaviors in analyzed company confirmed it.
\end{abstract}

Keywords: corporate social; responsibility; csr reports; garment industry; business ethics. 